\title{
NADZIEJA PODSTAWOWA A POCZUCIE SENSU ŻYCIA I LĘK PRZED ŚMIERCIĄ U MŁODZIEŻY AKADEMICKIEJ
}

\begin{abstract}
Streszczenie: Celem prezentowanych badań była weryfikacja zależności między nadzieją podstawową a poczuciem sensu życia i lękiem przed śmiercią u młodzieży akademickiej. Zastosowano trzy metody do pomiaru zmiennych: Kwestionariusz Nadziei Podstawowej (BHI-12) Jerzego Trzebińskiego i Mariusza Zięby, Skalę Sensu Życia (PLT) J. C. Crumbaugha oraz Kwestionariusz Lęku Przed Śmiercią i Umieraniem (FVTS) Randolfa Ochsmanna.

Uzyskane rezultaty badań potwierdzają postawione hipotezy o istnieniu związków pomiędzy poziomem nadziei podstawowej a poczuciem sensu życia i lękiem przed śmiercią: im wyższa nadzieja podstawowa, tym wyższe poczucie sensu życia oraz im wyższy poziom nadziei podstawowej, tym mniejszy lęk przed śmiercią. Lęk przed śmiercią w okresie podejmowania samodzielnego życia wyraża się przede wszystkim w obawie przed unicestwieniem, utratą własnego ,ja” oraz w lęku przed utratą bliskich osób.
\end{abstract}

Słowa kluczowe: nadzieja podstawowa, lęk przed śmiercią, poczucie sensu życia

\section{Wprowadzenie}

Od kilku dziesięcioleci obserwujemy wzrastające zainteresowanie nadzieją i rolą, jaką pełni ona w medycynie, filozofii, socjologii, antropologii, pedagogice czy psychologii. Okazuje się, że ten „subiektywny fenomen”, jak nazwał ją Józef Kozielecki (Kozielecki 2006, s.12), można już dzisiaj analizować za pomocą coraz bardziej subtelnych metod empirycznych i pomiarowych. Uwaga badaczy skupia się głównie wokół zagadnienia związanego z rolą, jaką pełni nadzieja w regulacji zachowania jednostki i społeczeństwa. Obecność nadziei w życiu człowieka pozwala mu odważniej iść przez życie. Wspiera sprawne i skuteczne działanie, pomaga osiągać sukcesy i dobrze radzić sobie z niepowodzeniami czy utratą wartości i celu. Z problematyką wartości zaś, jak się okazuje, ściśle związane są losy życiowe, $\mathrm{np}$. nieletnie matki istotnie niżej oceniły wartości prawdy w porównaniu z matkami współtworzącymi rodziny pełne (Skowroński 2013a).

Nadzieja w sposób istotny wpisana jest w życie każdego człowieka. Motywując i dynamizując podejmowane przez niego działania, przyczynia się do jego wszechstronnego i pełnego rozwoju. Brak nadziei natomiast często prowadzi do apatii, nudy, frustracji i rozpaczy. Rodzice, oczekując narodzenia dziecka, z nadzieją patrzą na dar życia, który się rozwija. Dziecko z ufnością kieruje swe spojrzenie na rodziców, którzy dają mu poczucie bezpieczeństwa, miłości i bliskości. Młody człowiek z nadzieją patrzy w przyszłość, choć jest ona odległa i nieznana. Małżeństwo przeżywające kryzys, w nadziei podejmuje 
wysiłki i wierzy, że przetrwa trudne momenty. Człowiek, który stracił pracę, z nadzieją patrzy w przyszłość, ufając, że znajdzie nową pracę. Więzień ma nadzieję na odzyskanie wolności, a chory na powrót do zdrowia i sił. Umierający człowiek z nadzieją oczekuje spotkania z Bogiem „bogatym w miłosierdzie”. W codziennym życiu człowieka nadzieja kreuje świat jako rzeczywistość bardziej ludzką. Stanowi ona rodzaj „wiatru w żagle”, dynamizującego i nadającego sens ludzkiemu życiu (Chrobak 2009). Nadzieja jest również ceniona jako wartość sama w sobie. Często jest ona źródłem radości, twórczych działań czy optymistycznych przekonań. Ponadto nadzieja, sprawiając, że spostrzegamy świat jako przyjazny, a teraźniejszość i przyszłość jako obszar szans i możliwości dla siebie i innych, wzmacnia poczucie sensu istnienia.

\section{Psychologiczne ujęcia nadziei}

Literatura psychologiczna w różny sposób ujmuje pojęcie nadziei. C. R. Snyder i Shane J. Lopez (2002) przedstawiają nadzieję jako emocję bądź jako optymistyczny styl myślenia ułatwiający osiągnięcie wysokiej jakości życia (Trzebiańska 2004). Ponadto nadzieja ujmowana jest również jako postawa przeciwstawna do depresji, rozpaczy czy pesymizmu (Seligman 1996).

Erich Fromm podkreśla, że posiadanie nadziei oznacza stałą, wewnętrzną gotowość jednostki do stawiania czoła wyzwaniom, które mają nadejść. W tym znaczeniu nadzieja jest wyrazem intensywnej - choć jeszcze niespełnionej - aktywności człowieka. Będąc związana ze sferą emocjonalną i poznawczą, towarzyszy człowiekowi na wszystkich etapach rozwoju człowieka (Fromm 2000).

Według Ericka Eriksona nadzieja to „oczekujące pragnienie”, siła popędowa, powstająca w wyniku rozwiązania pierwszego konfliktu rozwojowego między ufnością a nieufnością w 1 roku życia. Siła nadziei człowieka dorosłego, zdaniem amerykańskiego psychologa, uzależniona jest od tego, jak otoczenie rodzinne reagowało na potrzeby małego dziecka.

Martin Seligman zaproponował koncepcję wyuczonego optymizmu, opierającą się na założeniu, że optymizm człowieka znajduje swoje odzwierciedlenie w preferowanych sposobach interpretacji życiowych problemów oraz stosowania wyuczonych metod radzenia sobie. Stąd wyuczony optymizm jest przeciwnym stanem do wyuczonej bezradności (Seligman 1996).

C. R. Snyder postrzega nadzieję jako rodzaj myślenia nakierowanego na cel. Osoby posiadające nadzieję spostrzegają siebie jako zdolne do osiągnięcia pożądanego celu, poprzez sformułowanie konkretnych zadań i ich realizację (Snyder 200o). Roberto Zavalloni natomiast definiuje nadzieję jako oczekiwanie na wymarzony wynik. Nadzieja zatem odnosi się do czegoś pomyślnego, co ma nastąpić w przyszłości (Zavalloni 1999).

J. Kozielecki wyróżnił cztery rodzaje nadziei: generalną (związaną z poczuciem sensu życia i motywującą do działania zwłaszcza w sytuacjach określanych jako beznadziejne), partykularną (niosącą przekonanie, że w przyszłości zrodzą się nowe, ważne zadania nasycone pozytywnymi wartościami), aktywną (motywującą do osiągnięcia celu poprzez aktywowanie własnych umiejętności) oraz pasywną (będącą biernym oczekiwaniem) (Kozielecki 2006).

Kontynuując myśl E. Eriksona, J. Trzebiński i M. Zięba zaproponowali, aby do określenia nadziei zastosować termin „nadzieja podstawowa” (Trzebiński, Zięba 2003). Jest 
ona fundamentem, na którym jednostka buduje ogólne przekonanie o świecie: czy jest przychylny ludziom, czy nie. Ponadto tak rozumiana nadzieja decyduje o woli życia, motywacji do stawiania czoła trudnym zdarzeniom, a zwłaszcza nieodwracalnym stratom, takim jak śmierć bliskiej osoby (Jaślikowska 2003). Wpływa również na to, w jaki sposób jednostka reaguje na nowe, nieznane sytuacje. Osoby charakteryzujące się wysokim poziomem nadziei podstawowej, częściej niż osoby o niskim poziomie nadziei, postrzegają trudne sytuacje życiowe, jako wyzwanie i szansę na rozwój. Ponadto nadzieja podstawowa przeciwdziała syndromowi wyuczonej bezradności, w razie niepowodzenia i w sytuacji porażki pozwala uzyskać kontrolę nad biegiem zdarzeń (Trzebiński, Zięba 2003). Badania podejmujące problematykę nadziei, sensu życia młodzieży, obok problematyki wartości (Skowroński 2005), należą do tej grupy badań, które warto podejmować w sposób cykliczny, ze względu na dynamicznie zmieniającą się rzeczywistość społeczną (Skowroński 2013b).

\section{Metodologia badań własnych}

Celem pracy jest ukazanie związków pomiędzy intensywnością nadziei podstawowej a poczuciem sensu życia i lękiem przed śmiercią u młodzieży akademickiej.

Przedmiotem prezentowanych badań jest poszukiwanie odpowiedzi na pytania, czy u młodzieży akademickiej w tym okresie życia występują w stopniu znaczącym problemy związane z nadzieją podstawową, poczuciem sensu życia i lękiem przed śmiercią? Czy występują odrębności w nasileniu omawianych zjawisk u kobiet i mężczyzn? Czy występuje znacząca zależność między nadzieją podstawową a poczuciem sensu życia? Czy istnieje związek między nadzieją podstawową a lękiem przed śmiercią? Czy można mówić o znaczącej zależności pomiędzy poczuciem sensu życia a lękiem przed śmiercią?

Do tak nakreślonej problematyki sformułowano następujące hipotezy badawcze, których weryfikacja będzie przedmiotem badań empirycznych:

Hipoteza ogólna: zakłada się, że istnieje wyraźna zależność pomiędzy poziomem nadziei podstawowej a poczuciem sensu życia i lękiem przed śmiercią u młodzieży akademickiej. Hipotezy szczegółowe brzmią:

H 1. Przypuszcza się, że istnieje znamienna zależność między poziomem nadziei podstawowej a poczuciem sensu życia u młodzieży akademickiej.

H 2. Przypuszcza się, że istnieje statystycznie istotna zależność między poziomem nadziei podstawowej a lękiem przed śmiercią u młodzieży akademickiej.

H 3. Przypuszcza się, że występują znaczące różnice międzypłciowe w zakresie badanych zmiennych ujmowanych w tej pracy w badanych grupach osób.

Zaprezentowane hipotezy odnoszące się do związków nadziei podstawowej z poczuciem sensu życia i lęku przed śmiercią u młodzieży akademickiej wymagają weryfikacji empirycznej. W tym celu przeprowadzono badania psychologiczne, które pozwoliły na sformułowanie końcowych wniosków.

W celu weryfikacji hipotez do zbadania zmiennej niezależnej zastosowano Kwestionariusz Nadziei Podstawowej (BHI-12) J. Trzebińskiego i M. Zięby (2003), natomiast zmiennych zależnych: lęku przed śmiercią i poczucia sensu życia odpowiednio: Kwestionariusz Lęku Przed Śmiercią i Umieraniem (FVTS) R. Ochsmanna oraz Skalę Sensu Życia (PLT) J. C. Crumbaugha i L.T. Maholicka. 


\section{Kwestionariusz Nadziei Podstawowej (BHI-12) J. Trzebiński, M. Zięba}

Kwestionariusz BHI-12 jest narzędziem samoopisowym. Składa się z 12 stwierdzeń, przy których badany wybiera każdorazowo jedną z odpowiedzi na 5-stopniowej skali od „zdecydowanie nie zgadzam się” do „zdecydowanie się zgadzam”. Wynik to suma punktów, stanowiąca wskaźnik ogólnego poziomu nadziei podstawowej.

Wskaźnik zgodności wewnętrznej (alfa Cronbacha równy 0,70) opracowany został na podstawie ośmiu badań, prowadzonych w latach 2001-2003 na grupach licealistów ( $\mathrm{n}=558$ ). Stabilność narzędzia mierzona r-Pearsona wynosi o,62. Narzędzia BHI-12 można używać zarówno w badaniach naukowych, jak i w diagnozie indywidualnej.

\section{Kwestionariusz Lęku Przed Śmiercią i Umieraniem (FVTS) R. Ochsmanna}

Kwestionariusz jest wielowymiarową skalą badającą lęk przed śmiercią i umieraniem. Skala powstała w latach 9o. Składa się z 48 twierdzeń pogrupowanych w 6 różnych podskalach, służących do pomiaru niezależnych wymiarów lęku przed śmiercią. Ochsmann (1993) wyodrębnił te skale na podstawie wyników badań przeprowadzonych na 366 studentach różnych wydziałów uniwersytetu w Mannheim przy użyciu pierwotnej wersji FVTS, zawierającej 60 stwierdzeń. Średnia wieku badanych wynosiła 23,2 roku. W pierwszym etapie obróbki statystycznej dane zostały poddane analizie metodą czynników głównych osi z inercją zawartą w programie SPSS. Otrzymano 17 czynników, z których po obróbce „Screen Testem” Cattella wyekstrahowano 8 czynników. Następnie rozwiązanie dwu-ośmioczynnikowe zostało poddane rotacji prostokątnej według kryterium Varimax. Do wyliczenia optymalnej liczby czynników ekstrakcji zostało dołączone dodatkowe kryterium. Zgodnie z nim najbardziej optymalnym rozwiązaniem było takie, w którym wszystkie czynniki reprezentowane są przez przynajmniej trzy zmienne, oraz w którym najwięcej zmiennych jest podporządkowanych jakiemuś czynnikowi. Uzyskane w ten sposób dane pozwoliły wyodrębnić sześć czynników, które zostały wyrażone w 6 podskalach (Jastrzębski 2001):

1. (L1) lęk przed spotkaniem ze śmiercią. Osoby lękające się spotkania ze śmiercią charakteryzują następujące cechy, zachowania, postawy:

- nie mogłyby wejść do pomieszczenia, w którym ktoś umiera;

- troszczenie się o umierającego byłoby dla nich bardzo trudne;

- boją się wejść do prosektorium; dotykanie zmarłego byłoby dla nich problemem;

- nie mogliby spać w jednym pokoju ze zmarłym;

- oglądanie zmarłego byłoby dla nich okropnym przeżyciem.

2. (L2) lęk przed śmiertelnością.

Osoby lękające się swej śmiertelności charakteryzują następujące cechy, zachowania, postawy:

- niepokoi je myśl, że nie mają aż tyle czasu, by zrealizować swoje wszystkie zamierzenia;

- boją się myśli, że po śmierci nie będą troszczyć się o swoich bliskich;

- pozostawienie bliskich osób na skutek śmierci wywołuje lęk;

- nie chciałyby umrzeć, zanim nie zrobią wszystkiego, co planowały;

- boją się śmierci, ponieważ sprawi ona ból ich przyjaciołom i znajomym.

3. (L3) lęk przed końcem swego życia 
Osoby lękające się końca swego życia:

- uważają, że to niedobrze, że ich życie ma koniec;

- niepokoi myśl, że śmierć oznacza koniec ich egzystencji;

- lękają się myśli, że w końcu muszą umrzeć;

- chciałyby być nieśmiertelne;

- boją się umierania.

4. (L4) lęk przed fizycznym zniszczeniem

Osoby lękające się zniszczenia swego ciała na skutek śmierci cechują następujące postawy:

- zależy im, aby troszczono się o ich grób;

- jest dla nich ważne, w czym będą pogrzebane;

- nie chcą, aby robiono sekcję ich zwłok;

- nie jest im obojętne, co się stanie z ich ciałem po śmierci;

- boją się myśli o spaleniu swego ciała po śmierci.

5. (L5) lęk przed życiem po śmierci

Osoby lękające się swego życia po śmierci:

- niepokoi myśl, że nie wiedzą, co będzie po śmierci;

- boją się śmierci, ponieważ nie wiedzą, co się z nimi stanie;

- boją się odpowiedzialności za swoje czyny po śmierci;

- boją się, że po śmierci nie zaznają spokoju;

- boją się stanąć przed swoim Stwórcą.

6. (L6) lęk przed procesem umierania

Osoby lękające się umierania:

- boją się śmierci przez uduszenie lub utopienie;

- boją się umierania w ciężkich cierpieniach;

- boją się powolnej śmierci;

- boją się długiej choroby przed śmiercią;

- boją się śmierci wskutek ogromnego cierpienia.

Ostatnim wymiarem lęku przed śmiercią wyróżnionym przez Ochsmanna jest ogólny poziom lęku przed śmiercią (OPLpŚ), który w kwestionariuszu stanowi prostą sumę arytmetyczną wyników uzyskanych w pozostałych skalach.

Rzetelność FVTS oraz jego podskal została zweryfikowana metodą "test-retest” w Niemczech na grupie 78 osób w odstępie 3 miesięcy. Współczynniki rzetelności dla poszczególnych skal przedstawiają się następująco:

- (L1) lęk przed spotkaniem ze śmiercią r.tt. $=.66$

- (L2) lęk przed śmiertelnością r.tt. $=.82$

- (L3) lęk przed końcem życia r.tt.= .70

- (L4) lęk przed fizycznym zniszczeniem r.tt. $=.84$

- (L5) lęk przed życiem po śmierci r.tt. $=.70$

- (L6) lęk przed procesem umierania r.tt. $=.75$

- (OPLpŚ) ogólny poziom lęku przed śmiercią r.tt. $=.86$

W Polsce rzetelność Kwestionariusza FVTS ustaliła Eliza Rolińska (Rolińska 1994). W badaniach wzięła udział grupa 32 studentek i studentów III i IV roku psychologii Akademii Teologii Katolickiej w wieku 21-28 lat. Rolińska uzyskała następujące współczynniki rzetelności: 
- L1 r.tt. $=.96$;

- L2 r.tt. $=.97$;

- L3 r.tt. $=.96$;

- L4 r.tt.=.96;

- L5 r.tt. $=.87$;

- L6 r.tt.=.93;

- OPLpŚ r.tt.= .98 .

Zarówno Ochsmann, jak i autorka polskiej adaptacji kwestionariusza nie badali jego trafności.

\section{Skala Sensu Życia (PLT) J. C. Crumbaugha i L.T. Maholicka}

Skala PLT jest metodą badania poczucia sensu życia. Została opublikowana w 1963 r. jako „Test Celu Życia” (Purpose In Life Test - PIL). Znana także jako „Test Sensu Życia” (PLT). Skala została skonstruowana dla zbadania oceny sensowności i celu własnego życia. Jest oparta na teorii frustracji egzystencjalnej i nerwicy neogennej Victora Emila Frankla uważającego, że istnieje ścisły związek między zaburzeniami osobowości jednostki a poczuciem bezsensu - próżni egzystencjalnej (Juczyński 1982).

Autorem pierwszej wersji skali był Kotchen. Wersja druga jest wynikiem prac badawczych J. C. Crumbaugha i L. t. Maholicka.

Na dobrze ukształtowane poczucie sensu życia wskazują odpowiedzi w Skali Sensu Życia, w których badany mówi m.in., że:

- jego istnienie jest celowe i sensowne;

- zawsze znajduje wytłumaczenie dla swojego życia;

- każdy dzień niesie ze sobą coś nowego;

- gdyby miał umrzeć dziś, miałby poczucie, że jego życie było wartościowe;

- kieruje i kontroluje swoje życie;

- ma wyraźne cele dające pełne zadowolenie;

- w dążeniu do celów życiowych udało mu się zaspokajać swoje potrzeby;

- jego szanse na znalezienie sensu życia, celu i roli w życiu są bardzo duże;

- codzienne obowiązki są źródłem zadowolenia i radości.

O braku silnego poczucia sensu życia świadczą odpowiedzi, w których badany stwierdza m.in., że:

- często zastanawia się, po co żyje;

- jego istnienie jest zupełnie bezcelowe;

- gdyby miał możliwość wyboru, to wolałby nigdy się nie narodzić;

- wydaje mu się, że życie jest zupełnie szare;

- życie wymyka mu się z rąk kierowane przez innych;

- brak mu celu w życiu;

- jego życie jest puste i pełne rozpaczy;

- jego szanse na znalezienie sensu życia, celu i roli w życiu są praktycznie żadne;

- codzienne obowiązki są przykre i pełne udręki.

Rzetelność obliczona została przy pomocy współczynnika korelacji według wzoru Pearsona i wyniósł r.tt. $=0,81$, a po korekcie według wzoru Spearmana-Browna r.tt. $=0,90$. Stabilność skali wyniosła od r.tt. $=0,56$ do r.tt. $=0,68$. 
Dla określenia trafności skali PLT badano korelacje z innymi kwestionariuszami. Istnieje wysoka korelacja między kwestionariuszem Frankla a Skalą PLT, a także między skalą depresji D z MMPI a Skalą PLT (choć skala PLT nie może być używana jako skala depresji). Ponadto PLT koreluje również ze Skalą Zrównoważenia Afektywnego ( Siek 1993).

W celu weryfikacji hipotez badawczych dane uzyskane w toku przeprowadzonych badań własnych, poddano analizie statystycznej. Dokonano następujących czynności:

a) ocena związków pomiędzy poziomem nadziei podstawowej a stopniem poczucia sensu życia - w całej grupie i osobno dla każdej płci;

b) ocena związków pomiędzy poziomem nadziei podstawowej a poszczególnymi rodzajami lęku przed śmiercią - w całej grupie i osobno dla każdej płci;

c) porównanie stopnia sensu życia i poziomu poszczególnych rodzajów lęku przed śmiercią u osób o niskim i wysokim poziomie nadziei podstawowej.

Przy doborze metod analizy wzięto pod uwagę interwałową (przedziałową) skalę pomiaru oraz liczebność prób. Przy wyodrębnianiu osób o niskich i wysokich wynikach oparto się na kwartylach. Z uwagi na niedużą liczebność porównywanych prób zdecydowano się nie dokonywać oceny normalności rozkładu i wykorzystać nieparametryczny test U Manna-Whitneya posiadający $98 \%$ mocy testu t-Studenta.

Wykorzystano następujące metody statystyczne:

1. dla porównań międzygrupowych - test U Manna-Whitneya (Wilcoxona), gdy nie potwierdzono normalności rozkładu zmiennej w porównywanych grupach;

2. dla oceny współzależności- współczynnik korelacji liniowej Pearsona - dla oceny związków liniowych;

3. dla prób większych niż 25 osób - współczynnik korelacji rang (kolejności) Spearmana - dla oceny związków innych niż liniowe.

Dotychczas przeprowadzone badania, zarówno w Polsce, jak i za granicą, których wyniki zostaną przedstawione w dalszej części pracy, nie pozwoliły jasno stwierdzić, czy istnieją zależności między nadzieją podstawową a poczuciem sensu życia i lękiem przed śmiercią.

Badania zostały przeprowadzone wiosną 2006 roku w grupie studentów IV i V roku Wydziału Pedagogicznego Szkoły Wyższej im. Pawła Włodkowica w Płocku. Przebadano 87 kobiet i 40 mężczyzn. Wybór próby był celowy. Wydaje się bowiem, że myślenie o sensie ludzkiego życia i śmierci intensyfikuje się wraz z wiekiem. Ponadto z wielu badań wynika, że poziom lęku przed śmiercią, rozumianego jako lęk przed utratą „ja” czy też lęk przed unicestwieniem, wzrasta w okresie wczesnej dorosłości, gdy młodzież akademicka, podejmuje pierwsze próby usamodzielniania się, poszukując pracy czy wchodząc w stałe związki małżeńskie (Makselon 1988). Dodatkowo nie bez znaczenia pozostaje również fakt, że osoby starsze częściej myślą o śmierci, z uwagi na to, że częściej stają wobec śmierci osób bliskich (Makselon 1981). 


\section{Wyniki badań własnych}

Pierwszym krokiem analizy było skorelowanie poziomu nadziei podstawowej ze stopniem poczucia sensu życia w całej próbie.

Tabela 1. Współczynniki korelacji nadziei podstawowej ze stopniem poczucia sensu życia

\begin{tabular}{|l|l|l|l|l|}
\hline & \multicolumn{3}{|c|}{ korelacja Pearsona } & \multicolumn{3}{l|}{ korelacja Spearmana } \\
& $\mathrm{R}$ & $\mathrm{P}$ & Rho & $\mathrm{p}$ \\
\hline Poczucie sensu życia & 0,43 & $\mathrm{o}_{\mathrm{OO0}}{ }^{* *}$ & $\mathrm{0}, 47$ & ${\mathrm{o}, 001^{* * *}}^{*}$ \\
\hline
\end{tabular}

źródło: opracowanie własne

Wartości wskaźników korelacji Pearsona i Spearmana są zbliżone i raczej na niskim poziomie istotności.

${ }^{* * *} \mathrm{p}<0,001$

Tabela 2. Współczynniki korelacji nadziei podstawowej z poszczególnymi rodzajami lęku przed śmiercią

\begin{tabular}{|l|l|l|l|l|}
\hline \multirow{2}{*}{} & \multicolumn{2}{|l|}{ korelacja Pearsona } & \multicolumn{2}{l|}{ korelacja Spearmana } \\
\cline { 2 - 5 } & $\mathrm{R}$ & $\mathrm{P}$ & $\mathrm{Rho}$ & $\mathrm{P}$ \\
\hline Lęk przed spotkaniem ze śmiercią & $-0,23$ & $0,007^{* *}$ & $-0,25$ & $0,003^{* *}$ \\
\hline Lęk przed śmiertelnością & $-0,41$ & $0,001^{* * *}$ & $-0,32$ & $0,001^{* * *}$ \\
\hline Lęk przed końcem swojego istnienia & $-0,27$ & $0,002^{* *}$ & $-0,24$ & $0,005^{* *}$ \\
\hline Lęk przed fizycznym zniszczeniem & $-0,20$ & $0,021^{*}$ & $-0,17$ & $0,052 \mathrm{t}$ \\
\hline Lęk przed życiem po śmierci & $-0,35$ & $0,001^{* * *}$ & $-0,34$ & $0,001^{* * *}$ \\
\hline Lęk przed procesem umierania & $-0,10$ & 0,235 & $-0,04$ & 0,586 \\
\hline
\end{tabular}

źródło: opracowanie własne

Najsilniejszy ujemny związek istotny statystycznie występuje pomiędzy nadzieją podstawową a lękiem przed śmiertelnością $r=-0,41$. A zatem można stwierdzić, że im poziom nadziei podstawowej jest wyższy, tym poziom lęku przed śmiercią zmniejsza się.

$$
\begin{aligned}
& { }^{* *} \mathrm{p}<0,001 \\
& { }^{*} \mathrm{p}<0,01 \\
& { }^{*} \mathrm{p}<0,05 \\
& \mathrm{t} \mathrm{p}<0,10
\end{aligned}
$$


Tabela 3. Współczynniki korelacji nadziei podstawowej ze stopniem poczucia sensu życia u kobiet

\begin{tabular}{|l|l|l|l|l|}
\hline \multirow{2}{*}{} & \multicolumn{2}{|l|}{ korelacja Pearsona } & \multicolumn{2}{l|}{ korelacja Spearmana } \\
\cline { 2 - 5 } & $\mathrm{R}$ & $\mathrm{P}$ & $\mathrm{R}$. & $\mathrm{P}$ \\
\hline Poczucie sensu życia & $\mathrm{0}, 38$ & $\mathrm{O}, \mathrm{OOO}^{* * *}$ & $\mathrm{O}, 44$ & $\mathrm{0}, 001^{* * *}$ \\
\hline
\end{tabular}

źródło: opracowanie własne

Korelacja pomiędzy nadzieją podstawową a stopniem poczucia sensu życia u kobiet wynosi $\mathrm{r}=0,38$, co wskazuje na stałą zależność, że im wyższy poziom nadziei podestowej, tym wyższy poziom poczucia sensu życia.

Tabela 4. Współczynniki korelacji nadziei podstawowej z poszczególnymi rodzajami lęku przed śmiercią u kobiet

\begin{tabular}{|l|l|l|l|l|}
\hline \multirow{2}{*}{} & \multicolumn{2}{|l|}{ korelacja Pearsona } & \multicolumn{2}{l|}{ korelacja Spearmana } \\
\cline { 2 - 5 } & $\mathrm{R}$ & $\mathrm{P}$ & $\mathrm{Rho}$ & $\mathrm{P}$ \\
\hline Lęk przed spotkaniem ze śmiercią & $-0,10$ & 0,318 & $-0,11$ & 0,298 \\
\hline Lęk przed śmiertelnością & $-0,29$ & $0,005^{* *}$ & $-0,19$ & $0,065 \mathrm{t}$ \\
\hline Lęk przed końcem swojego istnienia & $-0,14$ & 0,191 & $-0,16$ & 0,133 \\
\hline Lęk przed fizycznym zniszczeniem & $-0,16$ & 0,135 & $-0,15$ & 0,152 \\
\hline Lęk przed życiem po śmierci & $-0,33$ & $0,001^{\star *}$ & $-0,34$ & $0,001^{\star *}$ \\
\hline Lęk przed procesem umierania & $-0,10$ & 0,355 & $-0,03$ & 0,724 \\
\hline
\end{tabular}

źródło: opracowanie własne

Najsilniejszy związek istotny statystycznie u kobiet występuje pomiędzy poziomem nadziei podstawowej a lękiem przed życiem po śmierci i wynosi $r=-0,33$, co pozwala stwierdzić, że im wyższy poziom nadziei podstawowej, tym zmniejsza się poziom lęku przed życiem po śmierci.

Tabela 5. Współczynniki korelacji nadziei podstawowej ze stopniem poczucia sensu życia u mężczyzn

\begin{tabular}{|l|l|l|l|l|}
\hline & \multicolumn{2}{|l|}{ korelacja Pearsona } & \multicolumn{2}{l|}{ korelacja Spearmana } \\
\cline { 2 - 5 } & $\mathrm{R}$ & $\mathrm{P}$ & $\mathrm{Rho}$ & $\mathrm{P}$ \\
\hline Poczucie sensu życia & 0,50 & $0,001^{* * *}$ & 0,46 & $0,003^{* *}$ \\
\hline
\end{tabular}

źródło: opracowanie własne

Można stwierdzić, że zachodzi istotny statystycznie związek pomiędzy poziomem nadziei podstawowej a poziomem poczucia sensu życia u mężczyzn, na co wskazuje współczynnik Pearsona wynoszący $\mathrm{r}=0,50$. 
Tabela 6. Współczynniki korelacji nadziei podstawowej z poszczególnymi rodzajami lęku przed śmiercią u mężczyzn

\begin{tabular}{|l|l|l|l|l|}
\hline \multirow{2}{*}{} & \multicolumn{2}{|l|}{ korelacja Pearsona } & \multicolumn{2}{l|}{ korelacja Spearmana } \\
\cline { 2 - 5 } & $\mathrm{R}$ & $\mathrm{P}$ & $\mathrm{Rho}$ & $\mathrm{P}$ \\
\hline Lęk przed spotkaniem ze śmiercią & $-0,35$ & $0,023^{*}$ & $-0,38$ & $0,016^{\star}$ \\
\hline Lęk przed śmiertelnością & $-0,44$ & $0,003^{* *}$ & $-0,45$ & $0,004^{* *}$ \\
\hline Lęk przed końcem swojego istnienia & $-0,43$ & $0,005^{* *}$ & $-0,42$ & $0,008^{* \star}$ \\
\hline Lęk przed fizycznym zniszczeniem & $-0,15$ & 0,339 & $-0,14$ & 0,375 \\
\hline Lęk przed życiem po śmierci & $-0,33$ & $0,034^{*}$ & $-0,32$ & $0,041^{*}$ \\
\hline Lęk przed procesem umierania & $-0,10$ & 0,515 & $-0,06$ & 0,677 \\
\hline
\end{tabular}

źródło: opracowanie własne

Najsilniejszy ujemny związek istotny statystycznie występuje pomiędzy poziomem nadziei podstawowej a poziomem lęku przed śmiertelnością u mężczyzn i wynosi $\mathrm{r}=-0,44$. Można zatem stwierdzić, że im poziom nadziei podstawowej jest wyższy, tym poziom lęku przed śmiertelnością zmniejsza się.

Nie stwierdzono związku istotnego statystycznie pomiędzy poziomem nadziei podstawowej a lękiem przed fizycznym zniszczeniem i lękiem przed procesem umierania u mężczyzn.

Tabela 7. Porównanie stopnia poczucia sensu życia u osób o niskim i wysokim poziomie nadziei podstawowej

\begin{tabular}{|l|l|l|l|l|l|l|}
\hline & \multicolumn{2}{|l|}{ Niski poziom } & \multicolumn{2}{l|}{ Wysoki poziom } & U & P \\
\hline & $\mathrm{M}$ & $\mathrm{SD}$ & $\mathrm{M}$ & $\mathrm{SD}$ & & \\
\hline Poczucie sensu życia & 100,02 & 17,58 & 117,79 & 6,60 & 974 & $0,001^{* * *}$ \\
\hline
\end{tabular}

źródło: opracowanie własne

Wskaźnik istotności różnic pozwala na stwierdzenie, że w badanej grupie osoby o wysokim poziomie nadziei podstawowej odznaczają się większym stopniem poczucia sensu życia niż osoby o niskim poziomie nadziei podstawowej.

Tabela 8. Porównanie poziomu poszczególnych wskaźników lęku przed śmiercią u osób o niskim i wysokim poziomie nadziei podstawowej

\begin{tabular}{|c|c|c|c|c|c|c|}
\hline & \multicolumn{2}{|c|}{ Niski poziom } & \multicolumn{2}{|c|}{$\begin{array}{l}\text { Wysoki } \\
\text { poziom }\end{array}$} & \multirow[t]{2}{*}{$\mathrm{U}$} & \multirow[t]{2}{*}{$\mathrm{P}$} \\
\hline & $\mathrm{M}$ & SD & $\mathrm{M}$ & SD & & \\
\hline Lęk przed spotkaniem ze śmiercią & 11,54 & 4,16 & 8,23 & 4,17 & 319,5 & $0,001^{* * *}$ \\
\hline Lęk przed śmiertelnością & 12,85 & 3,30 & 8,64 & 5,11 & 303 & $0,001^{* * *}$ \\
\hline Lęk przed końcem swojego istnienia & 9,77 & 3,91 & 6,94 & 3,93 & 357 & $0,004^{* *}$ \\
\hline
\end{tabular}




\begin{tabular}{|c|c|c|c|c|c|c|}
\hline & \multicolumn{2}{|c|}{ Niski poziom } & \multicolumn{2}{|c|}{$\begin{array}{l}\text { Wysoki } \\
\text { poziom }\end{array}$} & \multirow[t]{2}{*}{$\mathrm{U}$} & \multirow[t]{2}{*}{$\mathrm{P}$} \\
\hline & M & SD & M & SD & & \\
\hline Lęk przed fizycznym zniszczeniem & 10,11 & 4,58 & 7,55 & 4,54 & 391,5 & $0,014^{*}$ \\
\hline Lęk przed życiem po śmierci & 9,37 & 3,91 & 5,64 & 3,80 & 299 & $0,001^{* * *}$ \\
\hline Lęk przed procesem umierania & 12,71 & 3,41 & 12,08 & 4,00 & 548 & 0,576 \\
\hline
\end{tabular}

źródło: opracowanie własne

Można stwierdzić, że występuje różnica istotna statystycznie u osób o niskim poziomie nadziei podstawowej i u osób o wysokim poziomie nadziei podstawowej. Osoby o wysokim poziomie nadziei podstawowej odznaczają się mniejszym stopniem poszczególnych wskaźników lęku przed śmiercią niż osoby o niskim poziomie nadziei podstawowej.

Nie stwierdzono różnicy istotnej statystycznie w stopniu lęku przed procesem umierania u osób o niskim i wysokim poziomie nadziei podstawowej.

Tabela 9. Porównanie stopnia poczucia sensu życia u kobiet o niskim i wysokim poziomie nadziei podstawowej

\begin{tabular}{|c|c|c|c|c|c|c|}
\hline & \multicolumn{2}{|c|}{ Niski poziom } & \multicolumn{2}{|c|}{ Wysoki poziom } & \multirow[t]{2}{*}{$\mathrm{U}$} & \multirow[t]{2}{*}{$\mathrm{P}$} \\
\hline & M & $\mathrm{SD}$ & M & SD & & \\
\hline Poczucie sensu życia & 99,26 & 18,71 & 116,94 & 8,31 & 292 & $0,001^{* *}$ \\
\hline
\end{tabular}

źródło: opracowanie własne

Wskaźnik istotności różnic pozwala na stwierdzenie, że w badanej grupie kobiety o wysokim poziomie nadziei podstawowej odznaczają się większym stopniem poczucia sensu życia niż kobiety o niskim poziomie nadziei podstawowej.

Tabela 10. Porównanie poziomu poszczególnych wskaźników lęku przed śmiercią u kobiet o niskim i wysokim poziomie nadziei podstawowej

\begin{tabular}{|l|l|l|l|l|l|l|}
\hline & \multicolumn{2}{l|l|}{$\begin{array}{l}\text { Niski } \\
\text { poziom }\end{array}$} & \multicolumn{2}{l|}{$\begin{array}{l}\text { Wysoki } \\
\text { poziom }\end{array}$} & U & P \\
\hline & M & SD & M & SD & & \\
\hline Lęk przed spotkaniem ze śmiercią & 11,63 & 3,89 & 10,78 & 4,23 & 160 & 0,557 \\
\hline Lęk przed śmiertelnością & 13,15 & 2,50 & 11,15 & 4,65 & 143 & 0,272 \\
\hline Lęk przed końcem swojego istnienia & 9,47 & 3,25 & 8,78 & 4,13 & 156,5 & 0,490 \\
\hline Lęk przed fizycznym zniszczeniem & 10,57 & 4,05 & 9,10 & 3,34 & 125 & 0,105 \\
\hline Lęk przed życiem po śmierci & 9,89 & 3,08 & 6,26 & 3,69 & 82 & $0,003^{* *}$ \\
\hline Lęk przed procesem umierania & 12,94 & 2,57 & 12,42 & 3,80 & 179 & 0,976 \\
\hline
\end{tabular}

źródło: opracowanie własne 
Różnica istotna statystycznie występuje jedynie w stopniu lęku przed życiem po śmierci u kobiet o niskim poziomie nadziei podstawowej i wysokim poziomie nadziei podstawowej. Kobiety o wysokim poziomie nadziei podstawowej odznaczają się mniejszym stopniem lęku przed śmiercią po śmierci niż kobiety o niskim poziomie nadziei podstawowej.

Tabela 11. Porównanie stopnia poczucia sensu życia u mężczyzn o niskim i wysokim poziomie nadziei podstawowej

\begin{tabular}{|l|l|l|l|l|l|l|}
\hline & \multicolumn{2}{|l|}{ Niski poziom } & \multicolumn{2}{l|}{ Wysoki poziom } & U & P \\
\hline & M & SD & M & SD & & \\
\hline Poczucie sensu życia & 101,2 & 19,93 & 120,81 & 4,28 & 84,5 & $0,040^{*}$ \\
\hline
\end{tabular}

źródło: opracowanie własne

Można stwierdzić, że w badanej grupie mężczyźni o wysokim poziomie nadziei podstawowej odznaczają się większym stopniem poczucia sensu życia niż mężczyźni o niskim poziomie nadziei podstawowej, co pokazuje wskaźnik istotności różnic.

Tabela 12. Porównanie poziomu poszczególnych wskaźników lęku przed śmiercią u mężczyzn o niskim i wysokim poziomie nadziei podstawowej

\begin{tabular}{|l|l|l|l|l|l|l|}
\hline & \multicolumn{2}{|l|}{ Niski poziom } & \multicolumn{2}{l|}{$\begin{array}{l}\text { Wysoki } \\
\text { poziom }\end{array}$} & U & P \\
\hline & M & SD & M & SD & & \\
\hline Lęk przed spotkaniem ze śmiercią & 11,3 & 4,62 & 7,63 & 3,74 & 25 & $0,037^{*}$ \\
\hline Lęk przed śmiertelnością & 11,2 & 4,36 & 6,27 & 3,74 & 19 & $0,012^{*}$ \\
\hline Lęk przed końcem swojego istnienia & 9 & 4,78 & 5,72 & 3,97 & 33,5 & 0,137 \\
\hline Lęk przed fizycznym zniszczeniem & 7,3 & 5,25 & 6,72 & 4,83 & 54 & 0,971 \\
\hline Lęk przed życiem po śmierci & 6,8 & 3,93 & 5,27 & 4,22 & 42 & 0,376 \\
\hline Lęk przed procesem umierania & 12 & 4,34 & 11,90 & 4,34 & 51 & 0,803 \\
\hline
\end{tabular}

źródło: opracowanie własne

Wskaźnik istotności różnic pozwala na stwierdzenie, że w badanej grupie mężczyźni o wysokim poziomie nadziei podstawowej odznaczają się mniejszym stopniem lęku przed spotkaniem ze śmiercią i mniejszym stopniem lęku przed śmiertelnością niż mężczyźni o niskim poziomie nadziei podstawowej.

\section{Dyskusja wyników badań}

Celem przedstawionej pracy była próba ukazania związków pomiędzy poziomem nadziei podstawowej a poczuciem sensu życia i lęku przed śmiercią u młodzieży akademickiej. Cel pracy został osiągnięty. Uzyskane i zaprezentowane powyżej wyniki są zadowalające i potwierdzają w dużej mierze wcześniejsze oczekiwania oraz pozwalają na scharakteryzowanie próby w zakresie poziomu nadziei podstawowej oraz poczucia sensu życia i lęku 
przed śmiercią. Hipoteza ogólna zakładająca, że istnieje wyraźna zależność pomiędzy poziomem nadziei podstawowej a poczuciem sensu życia i lękiem przed śmiercią u młodzieży akademickiej została częściowo potwierdzona.

Przeprowadzone badania wykazały, że występuje związek istotny statystycznie pomiędzy nadzieją podstawową a poziomem poczucia sensu życia w całej grupie i podgrupach kobiet i mężczyzn. Współczynnik korelacji nadziei podstawowej ze stopniem poczucia sensu życia, oceniony za pomocą r-Pearsona w całej grupie, wynosi o,43. Wynik wskazuje, że im wyższa jest nadzieja podstawowa, tym wyższe poczucie sensu życia. Tym samym została całkowicie potwierdzona hipoteza pierwsza o istnieniu wyraźnej zależności pomiędzy poziomem nadziei podstawowej a poczuciem sensu życia u młodzieży akademickiej. Dodatkowo wyniki przeprowadzone na podgrupach kobiet i mężczyzn podkreślają, że zarówno kobiety, jak i mężczyźni o wysokim poziomie nadziei podstawowej odznaczają się większym stopniem poczucia sensu życia niż kobiety i mężczyźni o niskim poziomie nadziei podstawowej. Wyniki przeprowadzonego badania korespondują z badaniami Trzebińskiego, który w nadziei podstawowej upatruje przekonania jednostki o obiektywnym porządku, sensie i przychylności świata (Trzebiński, Zięba 2003).

Hipoteza druga o istnieniu znamiennej zależności pomiędzy poziomem nadziei podstawowej a lękiem przed śmiercią została potwierdzona w znacznej mierze. Jedynie w przypadku lęku przed procesem umierania nie stwierdzono związku istotnego statystycznie. W pozostałych rodzajach lęku przed śmiercią zależność jest zadowalająca. Ponadto na uwagę zasługuje najsilniejszy ujemny związek pomiędzy poziomem nadziei podstawowej a lękiem przed śmiertelnością, który wynosi $r=-0,41$. Wydaje się prawdopodobne, że to właśnie nadzieja podstawowa, aktywizująca się w sytuacji zachwiania dotychczasowego ładu, ma istotne znaczenie w redukowaniu lęku przed śmiertelnością związanego z troską o plany, zamierzenia i cierpieniem bliskich osób.

Ostatnia z hipotez, dotycząca istnienia znaczących różnic międzypłciowych w zakresie badanych zmiennych, została potwierdzona częściowo. W przypadku zależności pomiędzy poziomem nadziei podstawowej a poczuciem sensu życia oczekiwania zostały pozytywnie potwierdzone zarówno w grupie kobiet $(r-P e a r s o n a=0,38)$, jak i mężczyzn (r-Pearsona $=0,50)$. Wyższy wynik uzyskany przez grupę mężczyzn może być efektem nierówno licznych grup kobiet i mężczyzn.

Natomiast w odniesieniu do zależności pomiędzy poziomem nadziei podstawowej i poziomem lęku przed śmiercią u kobiet i mężczyzn omawiana hipoteza potwierdziła się tylko częściowo. Najsilniejsze ujemne związki u mężczyzn wystąpiły pomiędzy poziomem nadziei podstawowej a lękiem przed śmiertelnością (r-Pearsona $=-0,44)$ oraz lękiem przed końcem swego istnienia $(r=-0,43)$. W grupie kobiet potwierdzenie tej ujemnej zależności otrzymaliśmy jedynie w przypadku lęku przed życiem po śmierci $(\mathrm{r}=-0,33)$ oraz lęku przed śmiertelnością $(\mathrm{r}=-0,29)$. Potwierdza to pogląd, że lęk przed śmiercią w okresie podejmowania samodzielnego życia, wyraża się w obawie przed unicestwieniem i utratą własnego „ja” oraz lęku przed utratą bliskich osób, karą po śmierci i przeżywaniu własnej skończoności. Uzyskane wyniki dotyczące lęku przed śmiertelnością potwierdzają wyniki badań Jastrzębskiego.

Z badań wynika także, że mężczyźni o wysokim poziomie nadziei podstawowej odznaczają się mniejszym stopniem lęku przed spotkaniem ze śmiercią i mniejszym stopniem lęku przed śmiertelnością niż mężczyźni o niskim poziomie nadziei podstawowej. 
W przypadku kobiet o wysokim poziomie nadziei podstawowej, mniejszy poziom lęku przed śmiercią, dotyczy jedynie lęku przed życiem po śmierci niż kobiet o niskim poziomie nadziei podstawowej. W pozostałych rodzajach lęku przed śmiercią nie stwierdzono różnic istotnych statystycznie między mężczyznami i kobietami o niskim i wysokim poziomie nadziei podstawowej.

Jak wspomniano we wstępie, wyniki mogą mieć również praktyczne implikacje. Wydaje się bowiem, że wciąż zbyt mały nacisk kładziony jest na edukację zwłaszcza młodych rodziców, dotyczącą ich szczególnej roli w opiece nad dzieckiem w okresie o-3 r.ż. Wyniki wskazują, że poziom nadziei podstawowej, która kształtuje się w tym okresie, ma istotne znaczenie dla życia jednostki na kolejnych etapach rozwojowych. Skuteczna odpowiedź rodziców na potrzeby dziecka (zarówno fizjologiczne, jak i psychiczne) służy ukształtowaniu w nim wysokiego poziomu nadziei podstawowej, co z kolei może zaowocować w przyszłości otwartością na świat; będzie decydować o sile woli dziecka i tworzeniu silnej motywacji do stawania czoła trudnym sytuacjom.

Ponadto wydaje się, że w przyszłości ważną zmienną, która uzupełniłaby przeprowadzone badania i znacznie poszerzyła rozumienie badanego przedmiotu, byłaby zmienna kontrolująca postawę religijną osób badanych. Otrzymane w ten sposób wyniki, pozwoliłby na uchwycenie związków postawy religijnej i poziomu lęku przed śmiercią oraz poczucia sensu życia.

Dodatkowo warto byłoby przeprowadzić badania na takich samych liczebnie grupach. Jest bowiem prawdopodobne, że gdyby w prezentowanym badaniu grupy kobiet i mężczyzn były jednakowo liczne wyniki badań mogłyby ulec zmianie.

$\mathrm{Z}$ uwagi na to, że nasze badania były przeprowadzone na Wydziale Pedagogiki, warto byłoby sprawdzić, jak przedstawiałyby się wyniki badań na innych wydziałach uczelni teologicznych, medycznych, technicznych czy ekonomicznych.

Podjęte w temacie pracy zagadnienia dotyczące nadziei podstawowej i jej związków z poczuciem sensu życia i lękiem przed śmiercią wydają się ważne i przydatne. Idąc za sugestiami literatury przedmiotu, podjęto badania własne, których analiza danych statystycznych doprowadziła do stwierdzenia, że występują zależności dotyczące badanych zmiennych, choć postawione hipotezy szczegółowe nie zostały potwierdzone całkowicie. Reasumując, należy stwierdzić, że:

- potwierdzona została zależność pomiędzy poziomem nadziei podstawowej a poczuciem sensu życia;

- potwierdził się także ujemny związek pomiędzy poziomem nadziei podstawowej a lękiem przed śmiercią, choć nie ze wszystkimi rodzajami lęku;

- pozytywnie zweryfikowane zostały różnice międzypłciowe dotyczące badanego zagadnienia.

Otrzymane wyniki dają możliwość wyprowadzenia następujących wniosków:

- poziom nadziei podstawowej może być ważnym wyznacznikiem i pomocą w odnalezieniu poczucia sensu życia i radzeniu sobie z lękiem przed śmiercią;

- osoby, które mają wysoki poziom nadziei podstawowej, odbierają świat jako sensowny i przychylny ludziom;

- osoby, które posiadają wysoki poziom nadziei podstawowej, mają mniejszy poziom lęku przed śmiercią. 
Związki nadziei podstawowej z poczuciem sensu życia i lękiem przed śmiercią wskazują jak ważnym składnikiem osobowości jest nadzieja podstawowa. W odniesieniu do przedstawionej grupy badawczej aktywizacja nadziei podstawowej może pełnić istotną rolę w okresie wczesnej dorosłości, kiedy to młodzież akademicka rozpoczyna dorosłe życie i podejmuje pierwsze samodzielne wyzwania życiowe oraz szuka odpowiedzi na istotne pytania dotyczące życia osobistego i społecznego.

\section{Bibliografia}

Chrobak S. (2009). Podstawy pedagogiki nadziei. Współczesne konteksty w inspiracji personalistyczno-chrześcijańskiej. Warszawa: Wydawnictwo UKSW.

Erikson E. (2002). Dopełniony cykl życia. Poznań: Wydawnictwo Rebis.

Fromm E. (200o). Rewolucja nadziei. Ku uczłowieczonej technologii. Poznań: Wydawnictwo Rebis.

Jastrzębski J. (2001). Emocjonalne i religijne uwarunkowania lęku przed śmiercią u młodzieży akademickiej. „Studia Psychologica”, nr 2, s. 83-120.

Jaślikowska A. (2003). Siła nadziei podstawowej a szukanie sensu życiowej straty. Warszawa: SWPS.

Juczyński Z. (1982). Nerwica neogenna w ujęciu V. E. Frankla i jej miejsce w systematyce zaburzeń nerwicowych. „Zdrowie Psychiczne”, nr 1-2, s. 48-57.

Kozielecki J. (2006). Psychologia nadziei. Warszawa: Wydawnictwo Akademickie Żak.

Makselon J. (1981). Specyfika postaw wobec śmierci. „Studia Philosophiae Christianae”, nr 2, s. 113-134.

Makselon J. (1988). Lęk wobec śmierci. Kraków: Wydawnictwo PTT.

Makselon J. (1990). Antropologiczne implikacje badań tanatopsychologicznych. „Przegląd Psychologiczny", t. 33, $\mathrm{nr}$ 1, s. 29-38.

Ochsmann R. (1993). Angst vor Tod und Sterben. Beitrage zur Thanato-Psychologie. Gottingen: Hogrefe.

Rolińska E. (1994). Poczucie sensu życia a lęk przed śmiercia u osób starszych (niepublikowana praca magisterska). Warszawa: ATK.

Seligman M. (1996). Optymizmu można się nauczyć. Poznań: Wydawnictwo Media Rodzina.

Siek S. (1993). Wybrane metody badania osobowości. Warszawa: Wydawnictwo ATK.

Skowroński B. (2005). Hierarchia wartości młodzieży szkót licealnych powszechnych i katolickich. „Wychowanie na co dzień”, nr 9 (144).

Skowroński B. (2013a). Wartości deklarowane nieletnich matek. „Seminare”, t. 34, s. 189-204.

Skowroński B. (2013b). Młodzież licealna wobec wartości. Wyniki badań z lat 2003-2012. W: Bartoszewski J., Swędrak J., Struzik E. (red.). Wychowanie: czy może obejść się bez duchowości? Sieradz: Wydawnictwo WSHE.

Snyder C. R. (200o). Handbook of Hope. Theory, Measures and Applications. San Diego: Laurence Academic Press.

Snyder C. R., Lopez S. J. (2002). Handbook of positive psychology. New York: Oxford University Press.

Trzebiańska E. (2004). Psychologia lepszego życia. „Charaktery”, nr 6, s. 30-31.

Trzebiński J., Zięba M. (2003). Nadzieja, strata, rozwój. „Psychologia Jakości Życia”, t. 2, nr 1, s. 5-33. 
Zavalloni R. (1999). Psychologia Nadziei. Kielce: Wydawnictwo Jedność.

\title{
BASIC HOPE AND A SENSE OF THE MEANING IN LIFE AND THE FEAR OF DEATH AMONG ACADEMIC ADOLESCENTS
}

\begin{abstract}
The aim of the study was to verify the relationship between basic hope and a sense of the meaning in life and the fear of death. Three methods were used to measure the variables: Basic Hope Inventory (BHI-12) of J. Trzebinski and M. Zieba, Purpose of Life Test (PLT) of J.C. Crumbaugh and L.T. Maholick and Fear of Death and Dying Scale (FVTS) of R. Ochsmann. The results of studies confirm hypotheses about the existence of relationships between the level of basic hope and a sense of meaning in life and fear of death. The higher the basic hope, the higher meaning of life; the higher the level of basic hope, the less fear of death. Fear of death during independent life period is expressed mainly in fear of annihilation, loss of one's "self" and the fear of losing people who one loves.

Key words: basic hope, sense of meaning in life, fear of death

Rafał Pabich - magister teologii i magister psychologii. Ukończył studia doktoranckie w Instytucie Psychologii Uniwersytetu Kardynała Stefana Wyszyńskiego w Warszawie. Jego zainteresowania intelektualne skupiają się wokół zagadnień związanych z tanatopsychologią, nadzieją podstawową, sensem życia oraz poczuciem jakości życia w okresie adolescencji i wczesnej dorosłości. Adres e-mail: rafapab@poczta.onet.pl
\end{abstract}

